\title{
FACTORS AFFECTING THE PERFORMANCE OF CONSTRUCTION PROJECTS IN THE GAZA STRIP
}

\author{
Adnan Enshassi ${ }^{1}$, Sherif Mohamed ${ }^{2}$, Saleh Abushaban ${ }^{3}$ \\ ${ }^{1}$ School of Civil Engineering, Islamic University of Gaza, P.O. Box 108, Gaza, Palestine \\ ${ }^{2}$ School of Engineering, Griffith University, Gold Coast Campus, QLD 4222, Australia \\ ${ }^{3}$ Continuing Education Center, Community College of Applied Science and Technology, \\ P.O. Box 1415, Gaza, Palestine \\ E-mail: ${ }^{1}$ enshassi@iugaza.edu.ps, ${ }^{2}$ s.mohamed@griffith.edu.au \\ Received 6 Nov 2008; accepted 3 Apr 2009
}

\begin{abstract}
Construction projects located in the Gaza Strip, Palestine suffer from many problems and complex issues. Consequently, the objective of this paper is to identify the factors affecting the performance of local construction projects; and to elicit perceptions of their relative importance. A comprehensive literature review was deployed to generate a set of factors believed to affect project performance. A total of 120 questionnaires were distributed to 3 key groups of project participants; namely owners, consultants and contractors. The survey findings indicate that all 3 groups agree that the most important factors affecting project performance are: delays because of borders/roads closure leading to materials shortage; unavailability of resources; low level of project leadership skills; escalation of material prices; unavailability of highly experienced and qualified personnel; and poor quality of available equipment and raw materials. Based on these findings, the paper recommends that: 1) project owners must work collaboratively with contractors and facilitate regular payments in order to overcome delays, disputes and claims; 2) project participants should actively have their input in the process of decision-making; and 3) continuous coordination and relationship between project participants are required through the project life cycle in order to solve problems and develop project performance.
\end{abstract}

Keywords: performance, owners, consultants, contractors, projects.

\section{Introduction}

Throughout the world, the business environment within which construction organizations operate continues to change rapidly. Organizations failing to adapt and respond to the complexity of the new environment tend to experience survival problems (Lee et al. 2001). With increasing higher users' requirements, environmental awareness and limited resources on one side, and high competition for construction business marketplace on the other side, contractors have to be capable of continuously improving their performance (Samson and Lema 2005).

A number of studies have been conducted to examine factors impacting on project performance in developing countries. Faridi and El-Sayegh (2006) reported that shortage of skills of manpower, poor supervision and poor site management, unsuitable leadership, shortage and breakdown of equipment among others contribute to construction delays in the United Arab Emirates. Hanson et al. (2003) examined causes of client dissatisfaction in the South African building industry and found that conflict, poor workmanship and incompetence of contractors to be among the factors which would negatively impact on project performance. Mbachu and Nkando (2007) established that quality and attitude to service is one of the key factors constraining successful project delivery in South Africa. The performance of contractors in Zambia is apparently below expectation; it is not uncommon to learn of local projects that have not been completed or significantly delayed. This poor performance of many local contractors has huge implications in terms of their competitiveness (Zulu and Chileshe 2008).

The construction industry is complex in its nature because it comprises large numbers of parties as owners (clients), contractors, consultants, stakeholders, and regulators. Despite this complexity, the industry plays a major role in the development and achievement of society's goals. It is one of the largest industries and contributes to about $10 \%$ of the gross national product (GNP) in industrialized countries (Navon 2005). Palestine is no exception; the local construction industry is one of the main economic engine sectors, supporting the Palestinian national economy. However, many local construction projects report poor performance due to many evidential project-specific causes such as: unavailability of materials; excessive amendments of design and drawings; poor coordination among participants, ineffective monitoring and feedback, and lack of project leadership skills (UNRWA 2006). The ever-important macro-level political and economic factors have also been related to poor projects performance (UNRWA 2006 \& 2007).

Project performance can be measured and evaluated using a large number of performance indicators that could be related to various dimensions (groups) such as time, 
cost, quality, client satisfaction, client changes, business performance, health and safety (Cheung et al. 2004; DETR 2000). Time, cost and quality are, however, the 3 predominant performance evaluation dimensions. Another interesting way of evaluating project performance is through 2 common sets of indicators (Pheng and Chuan 2006). The first set is related to the owner, users, stakeholders, and the general public; the groups of people, who will look at project performance from the macro viewpoint. The second set comprises the developer and the contractor; the groups of people who will look at project performance from the micro viewpoint.

Generally, performance dimensions may have one or more indicators, and could be influenced by various project characteristics. For example, Dissanayaka and Kumaraswamy (1999) found that project time and cost performances get influenced by project characteristics, procurement system, project team performance, client representation's characteristics, contractor characteristics, design team characteristics, and external conditions. Similarly, Iyer and Jha (2005) identified many factors as having influence on project cost performance, these include: project manager's competence, top management support, project manager's coordinating and leadership skills, monitoring and feedback by the participants, decision-making, coordination among project participants, owners' competence, social condition, economic condition, and climatic condition. Coordination among project participants, however, was identified as the most significant of all the factors, having maximum influence on cost performance. Interestingly, Love et al. (2005) examined project time-cost performance relationship, and their results indicate that cost is a poor predictor of time performance. Elyamany et al. (2007) introduced a performance evaluation model for construction companies in order to provide a proper tool for the company's owners, shareholders and funding agencies to evaluate the performance of construction companies in Egypt.

The above examples demonstrate that there is a plethora of factors with the potential to affect the different dimensions of project performance. As such, this paper builds upon the vast amount of published studies (Cheung et al. 2004; DETR 2000; Karim and Marosszeky 1999; Dissanayaka and Kumaraswamy 1999; Ofori et al. 2004; Samson and Lema 2002; Iyer and Jha 2005; Love et al. 2005; UNRWA 2006 \& 2007; Ugwu and Haupt 2007; Enshassi et al. 2007; Alinaitwe et al. 2007) in order to identify a comprehensive list of factors affecting the performance of construction projects. Following this, the paper reports on the findings of a survey targeting project owners, consultants and contractors, in an attempt to shed some light on how each project party perceives the relative importance of these factors. Finally, the paper formulates a number of recommendations in order to bridge the gap between the different perceptions thus improving the level of project performance in the Gaza Strip.

\section{Methodology}

A questionnaire survey was used to elicit the attitude of owners, consultants, and contractors towards the factors affecting the performance of construction projects in the Gaza Strip. Questionnaires were sent to randomly selected owners, consultants, and contractors. Consultants were identified from the listings of consultants association; the target populations of contractors were companies registered with Palestinian contractors union. 120 questionnaires were distributed as follows: 25 to owners; 35 to consultants; and 60 to contractors. 88 were received (response rate of 73\%) as follows: $17(70 \%)$ from owners; 25 (72\%) from consultants; and 46 (77\%) from contractors as respondents. The respondents were asked to indicate, based on their local experience the level of importance of each one of the identified 63 factors of performance on a five-point Likert scale as: not important, slightly, moderately, very, and extremely important. The questionnaire has been validated by the criterion-related reliability test which measures the correlation coefficient between the factors affecting the performance of construction projects in one field and the whole field, and structure validity test (Spearman test).

The respondents were experienced construction project managers, site engineers/office engineers, and organizations' managers (with average experience of 20 years in the construction industry). 63 factors believed to affect project performance were considered in this study and were listed under 10 groups based on the literature reviewed (Okuwoga 1998; Dissanayaka and Kumaraswamy 1999; Reichelt and Lynies 1999; Karim and Marosszeky 1999; Brown and Adams 2000; DETR 2000; Lehtonen 2001; Chan 2001; Samson and Lema 2002; Kuprenas 2003; Cheung et al. 2004; Iyer and Jha 2005; Navon 2005; Love et al. 2005; Ugwa and Haupt 2007). The performance factors were summarized and collected according to previous studies and others as recommended by local experts. The main groups considered in this paper are: time, quality, productivity, client satisfaction, regular and community satisfaction, people, health and safety, innovation and learning, and environment.

The relative importance index method (RII) was used herein to determine owners', consultants', and contractors' perceptions of the relative importance of the identified performance factors. The RII was computed as (Cheung et al. 2004; Iyer and Jha 2005; Ugwu and Haupt 2007):

$$
R I I=\frac{\sum W}{A \times N},
$$

where $\mathrm{W}$ is the weight given to each factor by the respondents and ranges from 1 to $5 ; \mathrm{A}$ - the highest weight $=5 ; \mathrm{N}-$ the total number of respondents.

To determine whether there is a significant degree of agreement among the 3 groups of respondents (owners, contractors and consultants), Kendall's coefficient of concordance is used as a measure of agreement among raters. Kendall's coefficient of concordance indicates the degree of agreement on a zero to one scale, and is computed by the following equation (Moore et al. 2003; Frimpong et al. 2003):

$$
W=\frac{12 U-3 m^{2} n(n-1)^{2}}{m^{2} n(n-1)},
$$


where:

$$
U=\sum_{i=1}^{n}\left(\sum R\right)^{2}
$$

$n$ - number of factors; $m$ - number of groups; $j$ - the factors $1,2, \ldots, \mathrm{N}$.

Null hypothesis: $\mathrm{H}_{0}$ : There is insignificant degree of agreement among owners, contractors and consultants.

- Alternative hypothesis: $\mathrm{H}_{1}$ : There is a statistically significant degree of agreement among owners, contractors and consultants.

\section{Results and discussion}

\subsection{Factors affecting the performance of construction projects}

Table 1 summarizes the computed RIIs and their ranks as perceived by the 3 responding groups.

Table 1. Summary of relative importance index and rank for factors affecting the performance of construction projects

\begin{tabular}{|c|c|c|c|c|c|c|}
\hline \multirow{2}{*}{ Performance factors } & \multicolumn{2}{|c|}{ Owner } & \multicolumn{2}{|c|}{ Consultant } & \multicolumn{2}{|c|}{ Contractor } \\
\hline & RII & Rank & RII & Rank & RII & Rank \\
\hline \multicolumn{7}{|l|}{ (1) Cost factors } \\
\hline Market share of organization & 0.600 & 54 & 0.709 & 39 & 0.726 & 39 \\
\hline Liquidity of organization & 0.729 & 31 & 0.842 & 5 & 0.839 & 10 \\
\hline Cash flow of project & 0.812 & 14 & 0.800 & 11 & 0.848 & 9 \\
\hline Profit rate of project & 0.694 & 38 & 0.776 & 14 & 0.739 & 38 \\
\hline Overhead percentage of project & 0.647 & 48 & 0.687 & 49 & 0.662 & 47 \\
\hline Project design cost & 0.500 & 63 & 0.688 & 43 & 0.582 & 63 \\
\hline Material and equipment cost & 0.812 & 14 & 0.776 & 14 & 0.813 & 16 \\
\hline Project labour cost & 0.741 & 27 & 0.744 & 22 & 0.739 & 37 \\
\hline Project overtime cost & 0.588 & 58 & 0.600 & 59 & 0.617 & 55 \\
\hline Motivation cost & 0.600 & 54 & 0.584 & 61 & 0.609 & 58 \\
\hline Cost of rework & 0.588 & 58 & 0.672 & 51 & 0.587 & 62 \\
\hline Cost of variation orders & 0.565 & 62 & 0.688 & 43 & 0.662 & 46 \\
\hline Waste rate of materials & 0.650 & 46 & 0.624 & 57 & 0.639 & 51 \\
\hline Regular project budget update & 0.638 & 50 & 0.742 & 24 & 0.743 & 35 \\
\hline Cost control system & 0.725 & 33 & 0.728 & 28 & 0.765 & 32 \\
\hline Escalation of material prices & 0.847 & 5 & 0.832 & 7 & 0.889 & 4 \\
\hline Differentiation of currency prices & 0.788 & 18 & 0.808 & 9 & 0.874 & 5 \\
\hline
\end{tabular}

\section{(2) Time factors}

\begin{tabular}{|c|c|c|c|c|c|c|}
\hline Site preparation time & 0.682 & 42 & 0.664 & 53 & 0.596 & 61 \\
\hline Planned time for construction & 0.753 & 26 & 0.760 & 18 & 0.765 & 30 \\
\hline Percentage of orders delivered late & 0.694 & 40 & 0.768 & 17 & 0.774 & 29 \\
\hline Time needed to implement variation orders & 0.706 & 35 & 0.704 & 40 & 0.693 & 43 \\
\hline Time needed to rectify defects & 0.659 & 44 & 0.672 & 51 & 0.639 & 50 \\
\hline Average delay in claim approval & 0.650 & 46 & 0.728 & 28 & 0.765 & 30 \\
\hline Average delay in regular payments & 0.824 & 11 & 0.776 & 14 & 0.839 & 11 \\
\hline Unavailability of resources & 0.871 & 3 & 0.858 & 2 & 0.904 & 3 \\
\hline Average delay because of closures leading to materials shortage & 0.941 & 1 & 0.896 & 1 & 0.943 & 1 \\
\hline \multicolumn{7}{|l|}{ (3) Quality factors } \\
\hline Conformance to specification & 0.882 & 2 & 0.808 & 9 & 0.822 & 13 \\
\hline Unavailability of competent staff & 0.859 & 4 & 0.848 & 3 & 0.865 & 6 \\
\hline Quality of equipment and raw materials & 0.835 & 9 & 0.840 & 6 & 0.861 & 7 \\
\hline Quality assessment system in organization & 0.706 & 35 & 0.712 & 35 & 0.743 & 34 \\
\hline Quality training/meeting & 0.659 & 45 & 0.728 & 28 & 0.674 & 44 \\
\hline \multicolumn{7}{|l|}{ (4) Productivity factors } \\
\hline Project complexity & 0.729 & 31 & 0.712 & 35 & 0.761 & 33 \\
\hline Number of new projects / year & 0.600 & 54 & 0.688 & 43 & 0.630 & 53 \\
\hline Management-labour relationship & 0.776 & 22 & 0.688 & 43 & 0.796 & 22 \\
\hline Absenteeism rate through project & 0.776 & 20 & 0.688 & 43 & 0.743 & 36 \\
\hline Sequencing of work according to schedule & 0.800 & 17 & 0.816 & 8 & 0.804 & 20 \\
\hline
\end{tabular}


End of Table 1

\begin{tabular}{c|c|c|c|c|c|c}
\hline \multirow{2}{*}{ Performance factors } & \multicolumn{2}{|c|}{ Owner } & \multicolumn{3}{|c|}{ Consultant } & \multicolumn{2}{c}{ Contractor } \\
\cline { 2 - 6 } & RII & Rank & RII & Rank & RII & Rank \\
\hline
\end{tabular}

\section{(5) Client satisfaction factors}

Information coordination between owner and project parties

Leadership skills for project manager

Speed and reliability of service to owner

Number of disputes between owner and project parties

Number of rework incidents

\begin{tabular}{|c|c|c|c|c|c}
\hline 0.729 & 29 & 0.792 & 12 & 0.809 & 19 \\
\hline 0.835 & 7 & 0.848 & 3 & 0.904 & 2 \\
\hline 0.718 & 34 & 0.744 & 22 & 0.822 & 13 \\
\hline 0.753 & 24 & 0.728 & 28 & 0.720 & 40 \\
\hline 0.635 & 51 & 0.712 & 35 & 0.627 & 54 \\
\hline
\end{tabular}

\section{(6) Regular and community satisfaction factors}

\begin{tabular}{|c|c|c|c|c|c|c|}
\hline Cost of compliance to regulators requirements & 0.600 & 54 & 0.648 & 55 & 0.604 & 59 \\
\hline Number of non-compliance events & 0.635 & 51 & 0.624 & 57 & 0.614 & 56 \\
\hline Quality and availability of regulator documentation & 0.647 & 49 & 0.736 & 25 & 0.653 & 48 \\
\hline Site condition problems & 0.788 & 18 & 0.712 & 35 & 0.707 & 41 \\
\hline \multicolumn{7}{|l|}{ (7) People factors } \\
\hline Employee attitudes & 0.682 & 41 & 0.728 & 28 & 0.795 & 23 \\
\hline Recruitment and competence development & 0.753 & 24 & 0.688 & 43 & 0.809 & 17 \\
\hline Employees motivation & 0.765 & 23 & 0.696 & 42 & 0.791 & 24 \\
\hline Belonging to work & 0.835 & 9 & 0.736 & 25 & 0.849 & 8 \\
\hline \multicolumn{7}{|l|}{ (8) Health and safety factors } \\
\hline Application of health and safety factors in organization & 0.700 & 37 & 0.728 & 28 & 0.787 & 25 \\
\hline Project location is safe to reach & 0.694 & 38 & 0.704 & 40 & 0.774 & 28 \\
\hline Reportable accidents rate in project & 0.729 & 29 & 0.680 & 50 & 0.600 & 60 \\
\hline Assurance rate of project & 0.671 & 43 & 0.632 & 56 & 0.635 & 52 \\
\hline \multicolumn{7}{|l|}{ (9) Innovation and learning factors } \\
\hline Learning from own experience and past history & 0.847 & 5 & 0.752 & 20 & 0.818 & 15 \\
\hline Learning from best practice and experience of others & 0.824 & 12 & 0.760 & 18 & 0.822 & 12 \\
\hline Work group & 0.776 & 20 & 0.736 & 25 & 0.787 & 27 \\
\hline Review of failures and solving them & 0.824 & 12 & 0.752 & 20 & 0.809 & 17 \\
\hline \multicolumn{7}{|l|}{ (10) Environmental factors } \\
\hline Air quality & 0.588 & 58 & 0.592 & 60 & 0.671 & 45 \\
\hline Noise level & 0.565 & 61 & 0.512 & 63 & 0.613 & 57 \\
\hline Wastes around the site & 0.635 & 51 & 0.584 & 61 & 0.649 & 49 \\
\hline Climate condition & 0.729 & 28 & 0.656 & 54 & 0.707 & 41 \\
\hline
\end{tabular}

Table 2. The top significant factors affecting the performance of construction projects

\begin{tabular}{l|c|c|c|c|c|c}
\hline \multicolumn{1}{c|}{ Factors } & \multicolumn{2}{c|}{ Owner } & \multicolumn{3}{c}{ Consultant } & \multicolumn{2}{c}{ Contractor } \\
\cline { 2 - 7 } & RII & Rank & RII & Rank & RII & Rank \\
\hline Escalation of material prices & 0.847 & 5 & 0.832 & 7 & 0.889 & 4 \\
\hline Unavailability of resources as planned through the project duration & 0.871 & 3 & 0.858 & 2 & 0.904 & 3 \\
\hline Average delay because of closures leading to materials shortage & 0.941 & 1 & 0.896 & 1 & 0.943 & 1 \\
\hline Unavailability of personals with high experience and qualification & 0.859 & 4 & 0.848 & 3 & 0.865 & 6 \\
\hline Quality of equipments and raw materials in project & 0.835 & 9 & 0.840 & 6 & 0.861 & 7 \\
\hline Leadership skills for project manager & 0.835 & 7 & 0.848 & 3 & 0.904 & 2 \\
\hline
\end{tabular}

Table 2 illustrates the top significant factors affecting the performance of construction projects. It can be inferred from this table that 3 most important factors according to the perception of owner, consultant, and contractor are: average delay because of closures leading to materials shortage, unavailability of resources, and leadership skills for project manager.
According to owners, consultants, and contractors, it seems that the average delay because of closures leading to materials shortage was the most important performance factor as it has the first rank among all factors with relative index (RII) $=0.941$ for owners, 0.896 for consultants, and 0.943 for contractors. This agreement between all target groups is traced to the difficult political situation 
Table 3. Summary of relative importance index and rank of major groups affecting the performance of construction projects

\begin{tabular}{l|c|c|c|c|c|c}
\hline \multirow{2}{*}{\multicolumn{1}{c|}{ Performance groups }} & \multicolumn{2}{c|}{ Owner } & \multicolumn{2}{c|}{ Consultant } & \multicolumn{2}{c}{ Contractor } \\
\cline { 2 - 7 } & RII & Rank & RII & Rank & RII & Rank \\
\hline Cost & 0.679 & 8 & 0.724 & 5 & 0.726 & 7 \\
\hline Time & 0.753 & 4 & 0.757 & 3 & 0.769 & 5 \\
\hline Quality & 0.792 & 2 & 0.787 & 1 & 0.794 & 3 \\
\hline Productivity & 0.736 & 5 & 0.718 & 6 & 0.747 & 6 \\
\hline Client satisfaction & 0.734 & 6 & 0.765 & 2 & 0.779 & 4 \\
\hline Regular and community satisfaction & 0.668 & 9 & 0.680 & 9 & 0.646 & 10 \\
\hline People & 0.759 & 3 & 0.712 & 7 & 0.812 & 1 \\
\hline Health and safety & 0.698 & 7 & 0.686 & 8 & 0.699 & 8 \\
\hline Innovation and learning & 0.821 & 1 & 0.744 & 4 & 0.804 & 2 \\
\hline Environment & 0.629 & 10 & 0.586 & 10 & 0.660 & 9 \\
\hline
\end{tabular}

from which the Gaza Strip suffers. Local construction projects suffer from a number of problems because of closures and materials shortage. These problems can be considered as an obstacle for time performance of projects.

As indicated in Table 3, the quality group has been ranked by the owners' respondents in the second position with RII equal to 0.792 . It has been ranked by the consultants' respondents in the first position with RII equal to 0.787 and has been ranked by the contractors' respondents in the third position with RII equal to 0.794 . This group is the most important one for consultants because consultants are interested in clients and technical factors. Consultants observed that quality of equipment and raw materials in project and availability of personnel with high qualifications strongly affect the quality performance of a project.

The people group has been ranked by the owners' respondents in the third position with RII equal to 0.759 . It has been ranked by the consultants' respondents in the 7th position with RII equal to 0.712 and has been ranked by the contractors' respondents in the first position with RII equal to 0.812 . It is not surprising to observe that the peop- le group is the most important one for contractors because contractors remarked on competence development between employees and belonging to work strongly affect productivity, cost, and time performance of contractors.

The innovation and learning group has been ranked by the owners' respondents in the first position with RII equal to 0.821 . It has been ranked by the consultants' respondents in the 4 th position with RII equal to 0.744 and has been ranked by the contractors' respondents in the second position with RII equal to 0.804 . This group is the most important one for owners because owners remarked that learning from experience and training the human resources with skills demanded by the project strongly affect project performance.

The following is a brief discussion of the ranking of factors in groups, as shown in Table 1.

\subsubsection{Group one: cost factors}

The relative importance index (RII) and rank of cost factors are summarized in Table 4. Escalation of material prices has been ranked by the owners' and contractors'

Table 4. Summary of relative importance index and rank of cost factors

\begin{tabular}{l|c|c|c|c|c|c}
\hline \multirow{2}{*}{\multicolumn{1}{c}{ Cost factors group }} & \multicolumn{2}{c|}{ Owner } & \multicolumn{2}{c}{ Consultant } & \multicolumn{2}{c}{ Contractor } \\
\cline { 2 - 7 } & RII & Rank & RII & Rank & RII & Rank \\
\hline Market share of organization & 0.600 & 12 & 0.709 & 10 & 0.726 & 10 \\
\hline Liquidity of organization & 0.729 & 6 & 0.842 & 1 & 0.839 & 4 \\
\hline Cash flow of project & 0.812 & 2 & 0.800 & 4 & 0.848 & 3 \\
\hline Profit rate of project & 0.694 & 8 & 0.776 & 5 & 0.739 & 9 \\
\hline Overhead percentage of project & 0.647 & 10 & 0.687 & 13 & 0.662 & 12 \\
\hline Project design cost & 0.500 & 17 & 0.688 & 11 & 0.582 & 17 \\
\hline Material and equipment cost & 0.812 & 2 & 0.776 & 5 & 0.813 & 5 \\
\hline Project labour cost & 0.741 & 5 & 0.744 & 7 & 0.739 & 8 \\
\hline Project overtime cost & 0.588 & 14 & 0.600 & 16 & 0.617 & 14 \\
\hline Motivation cost & 0.600 & 12 & 0.584 & 17 & 0.609 & 15 \\
\hline Cost of rework & 0.588 & 14 & 0.672 & 14 & 0.587 & 16 \\
\hline Cost of variation orders & 0.565 & 16 & 0.688 & 11 & 0.662 & 11 \\
\hline Waste rate of materials & 0.650 & 9 & 0.624 & 15 & 0.639 & 13 \\
\hline Regular project budget update & 0.638 & 11 & 0.742 & 8 & 0.743 & 7 \\
\hline Cost control system & 0.725 & 7 & 0.728 & 9 & 0.765 & 6 \\
\hline Escalation of material prices & 0.847 & 1 & 0.832 & 2 & 0.889 & 1 \\
\hline Differentiation of currency prices & 0.788 & 4 & 0.808 & 3 & 0.874 & 2 \\
\hline
\end{tabular}


respondents in the first position. However, this factor has been ranked by the consultants' respondents in the second position. It is observed that this factor is more important for owners and contractors because escalation of material prices affects the liquidity of owners and the profit rate of contractors. Continuous closures of roads in the Gaza Strip lead to rapid shortages of construction materials and escalation of construction material prices.

Differentiation of currency prices has been ranked by the owners' respondents in the 4th position. It has been ranked by the consultants' respondents in the $3 \mathrm{rd}$ position and by the contractors' respondents in the second position. It is not surprising to find out differentiation of currency prices is more important for contractors than for others because this factor affects contractors' profit rate and cost performance. The cash flow of a project has been ranked by the owners' respondents in the second position. It has been ranked by the consultants' respondents in the 4th position and by the contractors' respondents in the 3 rd position. Cash flow is more important for owners and contractors than for consultants, because it can give an important evaluation for the owners' and the contractors' cost performance at any stage of project.

Material and equipment cost has been ranked by the owners' respondents in the second position, but it has been ranked by the consultants' and the contractors' respondents in the 5 th position. This indicates that this factor is more important for owners than for others. Material and equipment cost is one of the project cost components that affects owners' liquidity and project budget. Our results do not align with those of Iyer and Jha (2005) and Ugwu and Haupt (2007) as materials and equipment cost rarely affect the cost performance of Indian and South African construction projects. This can be attributed to different economic and political situations.

Liquidity of organisation has been ranked by the owners' respondents in the 6th position. It has been ranked by the consultants' respondents in the first position and by the contractors' respondents in the 4 th position. Consultants considered this factor as the most important one because cost performance of any project depends mainly on the organisation liquidity. Our result is in line with those of Samson and Lema (2002), as liquidity of the organisation is very important for evaluating of project budget and cost performance. However, Ugwu and Haupt (2007) are not in agreement with our results, as this factor is not important for owners and contractors while it is moderately important for consultants. This might be owing to different economic and political situations.

\subsubsection{Group two: time factors}

The relative importance index and rank of time factors are summarized in Table 5. According to owners, consultants, and contractors, the average delay because of closures leading to materials shortage was the most important performance factor, as it has the first rank among all factors with RII $=0.941$ for owners, 0.896 for consultants, and 0.943 for contractors. This agreement between all target groups is traced to the difficult political situation from which the Gaza Strip suffers. Local construction projects suffer from complex problems because of closures leading to materials shortage. These problems can be considered as an obstacle for time performance of projects.

Unavailability of resources as planned through project duration has been ranked by the owners' respondents in the 3rd position. It has been ranked by the consultants' respondents in the 2 nd position and by the contractors' respondents in the $3 \mathrm{rd}$ ane. This factor can be considered as important for 3 parties and scores a similar rank from all of them. This factor directly affects the project performance such as time. If resources are not available as planned through project duration, the project will suffer from the problem of time performance. Average delay in payment from owner to contractor has been ranked by the owners', consultants', and contractors' respondents in the 3rd position. This agreement between parties is traced to disputes that will happen between project parties, when the payment from owner is delayed. This will affect project performance, especially time criteria. Karim and Marosszeky (1999) are in agreement with our result, as the average delay in payment from owner to contractor affects the time performance.

Percentage of orders delivered late has been ranked by the owners' respondents in the 6th position and by the consultants' and contractors' respondents in the 4th position. This factor has the same rank for contractors and consultants and it is more important for them because it is related to contractual relationships between them. The contractor cannot implement any stage through a project

Table 5. Summary of relative importance index and rank of time factors

\begin{tabular}{l|c|c|c|c|c|c}
\hline \multirow{2}{*}{ Time factors group } & \multicolumn{2}{c|}{ Owner } & \multicolumn{2}{c|}{ Consultant } & \multicolumn{2}{c}{ Contractor } \\
\cline { 2 - 6 } & RII & Rank & RII & Rank & RII & Rank \\
\hline Site preparation time & 0.682 & 7 & 0.664 & 9 & 0.596 & 9 \\
\hline Planned time for project construction & 0.753 & 4 & 0.760 & 5 & 0.765 & 5 \\
\hline Percentage of orders delivered late & 0.694 & 6 & 0.768 & 4 & 0.774 & 4 \\
\hline Time needed to implement variation orders & 0.706 & 5 & 0.704 & 7 & 0.693 & 7 \\
\hline Time needed to rectify defects & 0.659 & 8 & 0.672 & 8 & 0.639 & 8 \\
\hline Average delay in claim approval & 0.650 & 9 & 0.728 & 6 & 0.765 & 5 \\
\hline Average delay in payment from owner to contractor & 0.824 & 3 & 0.776 & 3 & 0.839 & 3 \\
\hline Unavailability of resources as planned through project duration & 0.871 & 2 & 0.858 & 2 & 0.904 & 2 \\
\hline Average delay because of closures leading to materials shortage & 0.941 & 1 & 0.896 & 1 & 0.943 & 1 \\
\hline
\end{tabular}


without having orders from the project consultant. Planned time for project construction has been ranked by the owners' respondents in the 4th position and by the consultants' and contractors' respondents in the 5th position. This factor is more important for owners as they usually want their projects completed as early as possible.

\subsubsection{Group three: quality factors}

The relative importance index and rank of quality factors are summarized in Table 6. Unavailability of personnel with high experience and qualifications has been ranked by consultants' and contractors' respondents in the first position and by owners' respondents in the second one. This factor is very important for 3 parties because availability of personnel with high experience and qualifications assist them to implement their project with a professional and successful performance.

Participation of managerial levels in decisionmaking has been ranked by the owners', consultants', and contractors' respondents in the 4th position. This factor scored the same rank from all parties because sharing the managerial levels with decision-making will lead to better implementation and performance of a project and will satisfy the 3 parties to a greater degree. Iyer and Jha (2005) are in agreement with our results as this factor is important to 3 parties because it will improve overall performance of a construction project.

Conformance to specification has been ranked in the first position for owners, but it has been ranked in the $3 \mathrm{rd}$ position for both of consultants and contractors. This factor is more important for owners, as it is significant and related to client satisfaction. The owners usually seek to implement their project according to required specifications. Our results are align with those of Iyer and Jha (2005), as this factor is significant for owners because it is strongly related to client satisfaction. Quality of equipment and raw materials in a project has been ranked by the consultants' and contractors' respondents in the 2nd position and by the owners' respondents in the $3 \mathrm{rd}$ one. This factor is more important for consultants and contractors than for owners, as they usually want materials applied in a project to be of good quality and according to specification.

\subsubsection{Group four: productivity factors}

The relative importance index and rank of productivity factors are summarized in Table 7. Sequencing of work according to schedule has been ranked by owners, consultants, and contractors in the first position. This factor is the most important one for 3 parties because sequencing the work according to schedule assists them to conduct a project according to scheduled time for project completion. Our results are align with those of Samson and Lema (2002), as sequencing of work affects the productivity performance of contractors.

Management-labour relationship has been ranked by owners' and contractors' respondents in the 2 nd position and by consultants' respondents in the 3rd one. This factor is considered as important for 3 parties as management-labour relationship can assist them by strong coordination and motivation between labour level and managerial level. This will lead to an improvement in productivity and performance of projects.

Number of new projects per year has been ranked by owners' and contractors' respondents in the 5th position and has been ranked by consultants' respondents in the $3 \mathrm{rd}$ position. This factor is considered more important for consultants. Owners and contractors considered the number of new projects/year rarely affect the performance of projects. Consultants believed that number of new projects/year affect the degree of experiences and skills learned from executed projects and that will affect the degree of project performance based on previous or current experiences.

Table 6. Summary of relative importance index and rank of quality factors

\begin{tabular}{l|c|c|c|c|c|c}
\hline \multicolumn{1}{c}{ Quality factors group } & \multicolumn{2}{c|}{ Owner } & \multicolumn{2}{c}{ Consultant } & \multicolumn{2}{c}{ Contractor } \\
\cline { 2 - 7 } & RII & Rank & RII & Rank & RII & Rank \\
\hline Conformance to specification & 0.882 & 1 & 0.808 & 3 & 0.822 & 3 \\
\hline Unavailability of personals with high experience and qualification & 0.859 & 2 & 0.848 & 1 & 0.865 & 1 \\
\hline Quality of equipments and raw materials in project & 0.835 & 3 & 0.840 & 2 & 0.861 & 2 \\
\hline Participation of managerial levels with decision-making & 0.812 & 4 & 0.784 & 4 & 0.800 & 4 \\
\hline Quality assessment system in organization & 0.706 & 5 & 0.712 & 6 & 0.743 & 5 \\
\hline Quality training/meeting & 0.659 & 6 & 0.728 & 5 & 0.674 & 6 \\
\hline
\end{tabular}

Table 7. Summary of relative importance index and rank of productivity factors

\begin{tabular}{l|c|c|c|c|c|c}
\hline \multicolumn{1}{c}{ Productivity factors } & \multicolumn{2}{c|}{ Owner } & \multicolumn{2}{c|}{ Consultant } & \multicolumn{2}{c}{ Contractor } \\
\cline { 2 - 7 } & RII & Rank & RII & Rank & RII & Rank \\
\hline Project complexity & 0.729 & 4 & 0.712 & 2 & 0.761 & 3 \\
\hline Number of new projects/year & 0.600 & 5 & 0.688 & 3 & 0.630 & 5 \\
\hline Management-labour relationship & 0.776 & 2 & 0.688 & 3 & 0.796 & 2 \\
\hline Absenteeism rate through project & 0.776 & 2 & 0.688 & 3 & 0.743 & 4 \\
\hline Sequencing of work according to schedule & 0.800 & 1 & 0.816 & 1 & 0.804 & 1 \\
\hline
\end{tabular}


Table 8. Summary of relative importance index and rank of client satisfaction factors

\begin{tabular}{l|c|c|c|c|c|c}
\hline \multicolumn{1}{c}{ Client satisfaction group } & \multicolumn{2}{c|}{ Owner } & \multicolumn{2}{c}{ Consultant } & \multicolumn{2}{c}{ Contractor } \\
\cline { 2 - 7 } & RII & Rank & RII & Rank & RII & Rank \\
\hline Information coordination between owner and project parties & 0.729 & 3 & 0.792 & 2 & 0.809 & 3 \\
\hline Leadership skills for project manager & 0.835 & 1 & 0.848 & 1 & 0.904 & 1 \\
\hline Speed and reliability of service to owner & 0.718 & 4 & 0.744 & 3 & 0.822 & 2 \\
\hline Number of disputes between owner and project parties & 0.753 & 2 & 0.728 & 4 & 0.720 & 4 \\
\hline Number of reworks & 0.635 & 5 & 0.712 & 5 & 0.627 & 5 \\
\hline
\end{tabular}

Table 9. Summary of relative importance index and rank of regular and community satisfaction factors

\begin{tabular}{l|c|c|c|c|c|c}
\hline \multicolumn{1}{c}{ Regular and community satisfaction group } & \multicolumn{2}{c|}{ Owner } & \multicolumn{2}{c|}{ Consultant } & \multicolumn{2}{c}{ Contractor } \\
\cline { 2 - 7 } & RII & Rank & RII & Rank & RII & Rank \\
\hline Cost of compliance to regulators requirements & 0.600 & 4 & 0.648 & 3 & 0.604 & 4 \\
\hline Number of non-compliance to regulation & 0.635 & 3 & 0.624 & 4 & 0.614 & 3 \\
\hline Quality and availability of regulator documentation & 0.647 & 2 & 0.736 & 1 & 0.653 & 2 \\
\hline Neighbours and site conditions problems & 0.788 & 1 & 0.712 & 2 & 0.707 & 1 \\
\hline
\end{tabular}

Table 10. Summary of relative importance index and rank of people factors

\begin{tabular}{l|c|c|c|c|c|c}
\hline \multirow{2}{*}{ People factors group } & \multicolumn{2}{c|}{ Owner } & \multicolumn{2}{c}{ Consultant } & \multicolumn{2}{c}{ Contractor } \\
\cline { 2 - 7 } & RII & Rank & RII & Rank & RII & Rank \\
\hline Employee attitudes in project & 0.682 & 4 & 0.728 & 2 & 0.795 & 3 \\
\hline Recruitment and competence development between employees & 0.753 & 3 & 0.688 & 4 & 0.809 & 2 \\
\hline Employees motivation & 0.765 & 2 & 0.696 & 3 & 0.791 & 4 \\
\hline Belonging to work & 0.835 & 1 & 0.736 & 1 & 0.849 & 1 \\
\hline
\end{tabular}

\subsubsection{Group 5: client satisfaction factors}

The relative importance index and rank of client satisfaction factors are summarized in Table 8. Leadership skills for project managers have been ranked by owners', consultants', and contractors' respondents in the 1st position. This factor is the most important one for 3 parties because leadership skills for project managers affect the degree of project performance and client satisfaction. Cheung et al. (2004) observed that this factor is important for effectiveness of project performance. Our results are align with those of Cheung et al. (2004), as this factor is important for 3 parties because it is significant for effectiveness of project performance.

Number of reworks has been ranked by owners', consultants', and contractors' respondents in the 5th position. This factor has the same rank for 3 parties because number of reworks affect the relationship between them. Number of disputes between owner and project parties have been ranked by owners' respondents in the 2 nd position and by consultants' and contractors' respondents in the 4th position. This factor is more important for owners because disputes between owner and project parties will affect relationships between them and the degree of client satisfaction will be affected. All of that affects the performance of project. Information coordination between owner and project parties has been ranked by the owners' and contractors' respondents in the 3 rd position and by the consultants' respondents in the 2 nd position.

\subsubsection{Group 6: regular and community satisfaction factors}

The relative importance index and rank of regular and community satisfaction factors are summarized in Table 9. Neighbours and site condition problems have been ranked by the owners' and contractors' respondents in the 1 st position and by the consultants' respondents in the second one. This factor is more important for owners and contractors because it is strongly related to client satisfaction and contractors' performance.

Quality and availability of regulator documentation has been ranked by the consultants' respondents in the 1st position and by the owners' and contractors' respondents in the 2nd position. Quality and availability of regulator documentation is more important for consultants because it affects the performance of consultants and community satisfaction. This result is in line with Samson and Lema (2002), as this factor affects the contractors' performance because it affects regular and community satisfactions.

It can be understood, that there is a strong agreement between owners and contractors for ranking all regular and community satisfaction factors because they are more related to contractors' performance and client satisfaction. Generally, it can be said that 3 parties are in agreement for ranking these factors.

\subsubsection{Group 7: people factors}

The relative importance index and rank of people factors are summarized in Table 10.

Belonging to work it has been ranked by the owners, consultants, and contractors respondents in the first posi- 
tion. This factor is the most important one for 3 parties because belonging to work usually improves productivity and performance of project. Iyer and Jha (2005) are in agreement with our result as this factor is important for three parties because belonging to works improves productivity and performance of a project.

Employees' motivation has been ranked by the owners' respondents in the 2 nd position. It has been ranked by the consultants' respondents in the 3rd position and by the contractors' respondents in the 4th position. This factor is less important for contractors because it is rarely that contractors motivate employees in the Gaza Strip. Iyer and Jha (2005) remarked that this factor is moderately important for contractors because of absence of motivation systems in construction projects. However, other factors are ranked as more important for one party than others, as shown previously.

\subsubsection{Group 8: health and safety factors}

The relative importance index and rank of health and safety factors are summarized in Table 11. Application of health and safety factors in organizations has been ranked by the consultants' and contractors' respondents in 1st position, but has been ranked by the owners' respondents in the 2nd one. However, this factor is very important for 3 parties because application of health and safety factors in construction projects will improve overall performance of such projects. This result is in line with Cheung et al. (2004),_as this factor strongly affects the performance of projects because it affects the safety of employees.

Reportable accident rate in project has been ranked by the owners' respondents in the 1st position. It has been ranked by the consultants' respondents in the 3rd position and by the contractors' respondents in the 4th position. Owners considered this factor as the most important one, because reportable accident rate usually affects the safety performance and the client satisfaction degree in construction projects. Ease of access to the site (location of project) has been ranked by the owners' respondents in the 3rd position and by the consultants' and contractors' respondent in the 2 nd position. This factor is more impor- tant for consultants and contractors because the access to the site is more relevant to them and affects the degree of safety for their employees.

\subsubsection{Group 9: innovation and learning factors}

The relative importance index and rank of innovation and learning factors are summarized in Table 12. Learning from own experience and past history has been ranked by the owners' respondents in the 1 st position and by the consultants' and contractors' respondents in the 2nd position. This factor is more important for owners than for others. Owners can use their own experience and past history to improve and develop performance of their current and future projects. Samson and Lema (2002) remarked that learning from own experience and past history affects the performance of projects because it affects the innovation and learning required to construct projects.

Learning from best practice and experience of others has been ranked by the owners' respondents in the 3rd position and by the consultants' and contractors' respondents in the 1 st position. Contractors and consultants considered this factor as a more important one than owners did. This is because learning from best practice and experience of others can improve and develop consultants' and contractors' performance.

Training the human resources in the skills demanded by the project has been ranked by the owners' respondents in the 2 nd position. It has been ranked by the consultants' respondents in the 5th position and by the contractors' respondents in the 4th one. This factor is less important for contractors and consultants in the Gaza Strip, as they seldom train their employees in required and professional skills.

\subsubsection{Group 10: environmental factors}

The relative importance index and rank of environment factors are summarized in Table 13. Climate condition at the site has been ranked by the owners', consultants', and contractors' respondents in the 1st position. This factor is the most important one for them, because it affects the

Table 11. Summary of relative importance index and rank of health and safety factors

\begin{tabular}{l|c|c|c|c|c|c}
\hline \multicolumn{1}{c|}{ Health and safety factors group } & \multicolumn{2}{|c|}{ Owner } & \multicolumn{3}{c|}{ Consultant } & \multicolumn{2}{c}{ Contractor } \\
\cline { 2 - 7 } & RII & Rank & RII & Rank & RII & Rank \\
\hline Application of health and safety factors in organization & 0.700 & 2 & 0.728 & 1 & 0.787 & 1 \\
\hline Easiness to reach the site (location of project) & 0.694 & 3 & 0.704 & 2 & 0.774 & 2 \\
\hline Reportable accidents rate in project & 0.729 & 1 & 0.680 & 3 & 0.600 & 4 \\
\hline Assurance rate of project & 0.671 & 4 & 0.632 & 4 & 0.635 & 3 \\
\hline
\end{tabular}

Table 12. Summary of relative importance index and rank of innovation factors

\begin{tabular}{|c|c|c|c|c|c|c|}
\hline \multirow{2}{*}{ Innovation and learning factors } & \multicolumn{2}{|c|}{ Owner } & \multicolumn{2}{|c|}{ Consultant } & \multicolumn{2}{|c|}{ Contractor } \\
\hline & RII & Rank & RII & Rank & RII & Rank \\
\hline Learning from own experience and past history & 0.847 & 1 & 0.752 & 2 & 0.818 & 2 \\
\hline Learning from best practice and experience of others & 0.824 & 3 & 0.760 & 1 & 0.822 & 1 \\
\hline Training the human resources in the skills demanded by the project & 0.835 & 2 & 0.720 & 5 & 0.787 & 4 \\
\hline Work group & 0.776 & 5 & 0.736 & 4 & 0.787 & 4 \\
\hline Review of failures and solving them & 0.824 & 3 & 0.752 & 2 & 0.809 & 3 \\
\hline
\end{tabular}


Table 13. Summary of relative importance index and rank of environmental factors

\begin{tabular}{|c|c|c|c|c|c|c|}
\hline \multirow{2}{*}{ Environmental factors group } & \multicolumn{2}{|c|}{ Owner } & \multicolumn{2}{|c|}{ Consultant } & \multicolumn{2}{|c|}{ Contractor } \\
\hline & RII & Rank & RII & Rank & RII & Rank \\
\hline Air quality & 0.588 & 3 & 0.592 & 2 & 0.671 & 2 \\
\hline Noise level & 0.565 & 4 & 0.512 & 4 & 0.613 & 4 \\
\hline Wastes around the site & 0.635 & 2 & 0.584 & 3 & 0.649 & 3 \\
\hline Climate conditions & 0.729 & 1 & 0.656 & 1 & 0.707 & 1 \\
\hline
\end{tabular}

productivity and time performance of project. This result is not in agreement with Iyer and Jha (2005), as climate condition is not important for 3 parties. This might be because of different location, weather, and environment.

Noise level has been ranked by the owners', consultants', and contractors' respondents in the 4th position. However, for all parties a noise level is less important than other environmental factors because it is rarely an issue in the Gaza Strip. Ugwu and Haupt (2007) remarked that this factor is not important for owners and consultants but it is moderately important for contractors. Generally, noise level affects the productivity performance of construction projects.

\subsection{Degree of agreement among responding groups}

To determine whether there is a significant degree of agreement among the 3 groups (owners, contractors, and consultants) Kendall's coefficient of concordance is used as a measure of agreement among raters. For cost, time, quality, productivity, client satisfaction, people, innovation, and learning factors, and all groups together, the pvalues (Sig.) are less than $\alpha=0.05$ ( $\alpha$ is the level of significance), the null hypothesis, $\mathrm{H} 0$, is rejected and the alternative hypothesis, H1, is accepted. Therefore, it can be said that there is a significant degree of agreement among the owners, contractors and consultants regarding factors affecting the performance of construction projects in the Gaza Strip.

On the other hand, for regular and community satisfaction, health and safety, and environment factors, the pvalues (Sig.) are greater than $\alpha=0.05$ ( $\alpha$ is the level of significance), then we do not reject the null hypothesis, H0. Therefore, it can be said that there is an insufficient evidence to support the alternative hypothesis, H1. Hence, there is an insignificant degree of agreement among the owners, contractors, and consultants regarding factors affecting the performance of construction projects in the Gaza Strip.

\section{Conclusions}

A questionnaire-based survey was used to elicit the attitude of owners, consultants, and contractors towards factors affecting the performance of construction projects in the Gaza Strip. 120 questionnaires were distributed as follows: 25 to owners, 35 to consultants and 60 to contractors. 88 questionnaires $(73 \%)$ were returned as follows: 17 from owners, 25 from consultants, and 46 from contractors as respondents. The respondents were asked to indicate the level of importance of each of the 63 factors of performance in the Gaza Strip as not important, slightly, moderately, very, and extremely important.
The results indicated that the average delay because of closures leading to materials shortage was the most important performance factor, as it has the first rank among all factors from the perspectives of owners, consultants, and contractors. This agreement between all target groups is traced to the difficult political situation from which the Gaza Strip suffers. The most important factors agreed by the owners, consultants, and contractors as the main factors affecting the performance of construction projects in the Gaza Strip were: escalation of material prices, availability of resources as planned through project duration, average delay because of closures leading to materials shortage, availability of personnel with a high experience and qualifications, quality of equipment and raw materials in project, and leadership skills for project managers.

Kendall's coefficient of concordance is used to determine, whether there is a degree of agreement among performance factors for owners, consultants, and contractors. For cost, time, quality, productivity, client satisfaction, people, innovation, and learning factors, and all groups together, there is a significant degree of agreement among the owners, consultants, and contractors. This is because all owners, consultants, and contractors are concerned with these groups. On the other hand, for regular and community satisfaction, health and safety, and environment factors, there is an insignificant degree of agreement among the owners, consultants, and contractors. This is because contractors are concerned with these factors more or less than owners and consultants. The owners and consultants considered the client and technical factors to be more important than the operational ones.

The authors recommended to develop human resources in the construction industry through proper and continuous training programs about construction projects performance. These programs can update participants' knowledge and can assist them to be more familiar with project management techniques and processes. Owners are encouraged to facilitate payment to contractors in order to overcome delay, disputes, and claims. All managerial levels should participate in sensitive and important decision-making. Continuous coordination and relationship between project participants are required through project life cycle for solving problems and developing project performance.

Consultants should be more interested in design cost by using multi-criteria analysis and choosing the most economical criteria in order to improve their performance and to increase owners' satisfaction. In addition, consultants are urged to facilitate and expedite orders delivered to contractors to obtain better time performance and to minimize disputes and claims. Contractors should not 
increase the number of projects that cannot be performed successfully. In addition, contractors should consider political and business environment risks in their cost estimation for overcoming delay because of closures leading to materials shortages. There should be adequate contingency allowances in order to cover increases in material cost. Proper motivation and safety systems should be established for improving the productivity performance of construction projects in the Gaza Strip. Greater application of health and safety factors are necessary to overcome problems of safety performance.

Contractors are counseled to minimize waste rates through project implementation for improving cost. They should be more interested in conformance to project specification to overcome disputes, time, and cost performance problems. Quality materials should be of a greater interest for contractors in order to improve cost, time, and quality performance. This can be done by applying quality training and meetings that are necessary for performing an improvement. Contractors are urged to be more interested in sequencing of work according to schedule. In addition, contractors should have a cost engineer in their projects to successfully control costs.

\section{References}

Alinaitwe, H. M.; Mwakali, J. A.; Hansson, B. 2007. Factors affecting the productivity of building craftsmen studies of Uganda, Journal of Civil Engineering and Management 13(3): 169-176.

Brown, A.; Adams, J. 2000. Measuring the effect of project management on construction outputs: a new approach, International Journal of Project Management 18: 327-335.

Cavalieri, S.; Terzi, S.; Macchi, M. 2007. A benchmarking service for the evaluation and comparison of scheduling techniques, Computers in Industry 58: 656-666. doi:10.1016/j.compind.2007.05.004

Chan, A. P. C. 2001. Time-cost relationship of public sector projects in Malaysia, International Journal of Project Management 19: 223-229. doi:10.1016/S0263-7863(99)00072-1

Chan, A. P. C.; Chan, D. W. M. 2004. Developing a benchmark model for project construction time performance in Hong Kong, Building and Environment 39: 339-349. doi:10.1016/j.buildenv.2003.08.012

Chan, D. W. M.; Kumaraswamy, M. M. 2002. Compressing construction durations: lessons learned from Hong Kong building projects, International Journal of Project Management 20: 23-35. doi:10.1016/S0263-7863(00)00032-6

Cheung, S.-O.; Suen, H. C. H.; Cheung, K. K. W. 2004. PPMS: a Web-based construction project performance monitoring system, Automation in Construction 13: 361-376. doi:10.1016/j.autcon.2003.12.001

Department of the Environment, Transport and the Regions (DETR), (2000), KPI Report for the Minister for Construction by the KPI Working Group, January 2000.

Dissanayaka, S. M.; Kumaraswamy, M. M. 1999. Comparing contributors to time and cost performance in building projects, Building and Environment 34: 31-42. doi:10.1016/S0360-1323(97)00068-1

Elyamany, A.; Ismail, B.; Zayed, T. 2007. Performance evaluating model for construction companies: Egyptian case study, Journal of Construction Engineering and Management 133(8): 574-581.

doi:10.1061/(ASCE)0733-9364(2007)133:8(574)

Enshassi, A.; Mohamed, S.; Abu Mustafa, Z.; Mayer, P. E. 2007. Factors affecting labor productivity in building projects in the Gaza Strip, Journal of Civil Engineering and Management 13(4): 245-254.

Faridi, A.; El-Sayegh, S. 2006. Significant factors causing delay in the UAE construction industry, Construction Management and Economics 24(11): 1167-1176.

doi:10.1080/01446190600827033

Frimpong Yaw; Oluwoye, J.; Crawford, L. 2003. Causes of delay and cost overruns in construction of groundwater projects in a developing countries; Ghana as a case study, International Journal of Project Management 21: 321326. doi:10.1016/S0263-7863(02)00055-8

Hanson, D.; Mbachu, J.; Nkando, R. 2003. Causes of client dissatisfaction in the South African building industry and ways of improvement: the contractors' perspectives, in $C I D B$, South Africa.

Iyer, K. C.; Jha, K. N. 2005. Factors affecting cost performance: evidence from Indian construction projects, International Journal of Project Management 23: 283-295. doi:10.1016/j.ijproman.2004.10.003

Karim, K.; Marosszeky, M. 1999. Process monitoring for process re-engineering - using key performance indicators, International Conference on Construction Process Reengineering, CPR 99, Sydney, 12-13 July.

Kuprenas, J. A. 2003. Project management actions to improve design phase cost performance, Journal of Management in Engineering 19(1): 25-32. doi:10.1061/(ASCE)0742-597X(2003)19:1(25)

Lee, A.; Cooper, R.; Aouad, G. 2001. A methodology for designing performance measures for the UK construction industry. Salford University.

Lehtonen Tutu Wegelius. 2001. Performance measurement in construction logistics, International Journal of Production Economics 69: 107-116. doi:10.1016/S0925-5273(00)00034-7

Love, P. E. D.; Tse, R. Y. C.; Edwards, D. J. 2005. Time-cost relationships in australian building construction projects, Journal of Construction Engineering and Management 131(2): 187-194. doi:10.1061/(ASCE)0733-9364(2005)131:2(187)

Mbachu, J.; Nkando, R. 2007. Factors constraining successful building project implementation in South Africa, Construction Management and Economics 25(1): 39-54. doi:10.1080/01446190600601297

Moore, D.; McCabe, G.; Duckworth, W.; Sclove, S. 2003. The Practice of business statistics. Freeman, New York.

Navon, R. 2005. Automated project performance control of construction projects, Automation in Construction 14: 467-476. doi:10.1016/j.autcon.2004.09.006

Ofori, G.; Dulaimi, M. F.; Ling, F. Y. 2004. Improving performance of construction industry in Singapore: motivators, enablers and lessons for developing countries, Journal of Construction Research 5(2): 267-289. doi:10.1142/S1609945104000188

Okuwoga, A. A. 1998. Cost-time performance of public sector housing projects in Nigeria, Habitat Intl. 22(4): 389-395. doi:10.1016/S0197-3975(98)00014-9

Pheng, L. S.; Chuan, Q. T. 2006. Environmental factors and work performance of project managers in the construction 
industry, International Journal of Project Management 24: 24-37. doi:10.1016/j.ijproman.2005.06.001

Reichelt, K.; Lyneis, J. 1999. The dynamic of project performance: Benchmarking the drivers of cost and schedule overrun, European Management Journal 17(2): 135-150. doi:10.1016/S0263-2373(98)00073-5

Samson, M.; Lema, N. M. 2005. Development of construction contractors performance measurement framework. Department of Construction Technology and Management, University of Dar es Salaam, Tanzania.

Ugwu, O. O.; Haupt, T. C. 2007. Key performance indicators and assessment methods for infrastructure sustainability a South African construction industry perspective, Building and Environment 42: 665-680. doi:10.1016/j.buildenv.2005.10.018
UNRWA. 2006. Projects completion reports, UNRWA, Gaza.

UNRWA. 2007. Projects completion reports, UNRWA, Gaza.

World Bank. 2004. Infrastructure Assessment, Finance, Private Sector and Infrastructure Group, Middle East \& North Africa, December 2004.

Zulu, S.; Chileshe, N. 2008. The impact of service quality on project performance: a case study of building maintenance services in Zambia, in Proc. of the $3^{\text {rd }}$ Built Environment Conference, Association of Schools of Construction of Southern Africa, Cape Town, South Africa.

\section{VEIKSNIAI, LEMIANTYS STATYBOS PROJEKTŲ ĮGYVENDINIMĄ GAZOS RUOŽE}

\section{A. Enshassi, S. Mohamed, S. Abushaban}

\section{S a n tra u a}

Statybos projektai Gazos Ruože, Palestinoje, kenčia nuo daugelio problemų ir sudėtingų klausimų. Todèl pagrindinis šio straipsnio tikslas yra nustatyti veiksnius, darančius įtaką vietos statybos projektams igyvendinti, ugdyti suvokimą apie jų santykinę svarbą. Iš viso 120 respondentų buvo suskirstyti į tris pagrindines projektų dalyvių grupes: savininkai, konsultantai ir rangovai. Apklausa parodè, kad visos trys grupés sutinka, kad svarbiausi veiksniai, lemiantys projekto igyvendinimą, yra: atidèliojimas, susijęs su sienų (keliu) uždarymu ir lemiantis medžiagų stygių; negaunamos atsargos; menki vadovavimo projektams igūdžiai; nepagrịsta medžiagų kaina; patyrusio ir kvalifikuoto personalo stoka ir prasta įrankių ir žaliavos kokybė. Pasitelkiant šias išvadas, straipsnyje rekomenduojama: 1) projektų savininkai turi dirbti kartu su rangovais ir reguliariai atsiskaityti noredami išvengti atidèliojimų, ginčų ir pretenzijų; 2) projekto dalyviai turètų aktyviai dalyvauti priimant spendimus; 3 ) nuolatiné projekto dalyvių kontrolè ir jų tarpusavio santykis yra reikalingi per visą projekto igyvendinimo ciklą norint išspręsti iškilusias problemas ir igyvendinti projektą.

Reikšminiai žodžiai: igyvendinimas, savininkai, konsultantai, rangovai, projektai.

Adnan ENSHASSI is a Professor and Dean of the Faculty of Engineering at the Islamic University of Gaza (Palestine). Member in the international editorial board of the International Journal of Construction Management (HONGKONG); and the International Journal of Construction Project Management (CANADA). His research interest include safety in construction, productivity improvement, contract management, and risk analysis and management. Author and co-author of over 100 refereed journal and conference publications.

Sherif MOHAMED. Professor and Director of the Centre for Infrastructure Engineering and Management at Griffith University, Queensland (Australia). His research interest lies in the field of project and construction management, focusing mainly on the development of theoretical knowledge and operational tools needed for effective process management. Author and co-author of over 100 refereed journal and conference publications in the last 10 years.

Saleh ABUSHABAN is a research assistant at the Continuing Education Centre, CCAST, Palestine. His research interests include construction productivity and safety in construction. 